\title{
Phytochemical constituents of cultured cells of Eucalyptus tereticornis SM.
}

\author{
R. Venkateswara, S.Sankara Rao, and C.S. Vaidyanathan
}

Enzymology and Plant Biochemistry Laboratory, Department of Biochemistry, Indian Institute of Science, Bangalore 560012, India

Received August 23, 1985 / Revised version received April 10, 1986 - Communicated by F. Constabel

\section{ABSTRACT}

Callus induced from shoot explants of Eucalyptus tereticornis was maintained for eight months on a defined MS medium. The lipid composition of the callus of $E$. tereticornis were $B$-sitosterol, stigmasterol and cholesterol. In addition, we report the presence of a flavanoidal glycoside, aglycon identified as Kaempferol. Further, the presence of 2,3-dihydroxybenzaldehyde and 3,4-dihydroxyphenyl acetic acid was established from the methanol fraction.

List of Abbreviations: 2,4-D = 2,4-Dichlorophenoxyacetic acid, $\mathrm{Kn}=$ Kinetin, NAA = 1-Naphthaleneacetic acid, $\mathrm{IAA}=$ Indole-3-acetic acid, $\mathrm{BA}=6$-Benzylaminopurine.

\section{INTRODUCTION}

Eucalyptus is a large genus of subtropical and warm temperate evergreen aromatic trees indigenous to Australia, Tasmania and New Guiriea. About 100 species have been tried in India for valuable timber, pulp and paper production.

Most of the species are popularly known as Gum trees although the exudation from them is not a gum but an astringent, tanniferous polyphenol called Kino. Bark of Eucalyptus species contains varying proportions of polyphenols. They constitute an important source of tanning materials (Linchan, 1981).

Investigations of the phenolics of Eucalyptus have revealed the presence of eucalyptin, betulinic acid and urosolic acid from E.citriodora Wild. (Dayal Rameshwar, 1982), euglobal III from E. globulus (Sawad, 1980), robusteol-A (Qin Cuo-We, 1981) and later 7-0-methyl aromadendin, aromadendrin and fustin from E.citriodora (Dayal Rameshwar, 1981). Norolic acid was characterised from E. grossa by Cannon (1981). Earlier Wollenweber (1981) reported flavanoids from the cuticular layer of the leaf of E. ovata. Abd-Alla (1980) identified flavanoidal glycosides in two chemical races of $E$. camaldulensis corresponding to north and south populations of Australia.

Attempts to propagate Eucalyptus through tissue culture have been successful (De Fossard 1978, Gupta et al 1978,1982, 1983, Hartney and Barker 1980, Mehrapalta 1982, Bennet and McComb 1982, Durand-Cresswel 1982, Sankara Rao and Venkateswara 1985). The phytochemical investigations of the callus have not been carried out so far and we wish to report the generation of callus and subsequent phytochemical investigations of
E. tereticornis.

\section{MATERIAL AND METHODS}

Nodal and internodal segments from tender portions of actively growing branches of E. tereticornis plants raised in the Indian Institute of Science nursery were collected. They were surface sterilized with $0.1 \%$ mercuric chloride solution for 15 minutes and rinsed thoroughly with sterile distilled water. The material was further cut into pieces of suitable size $(10 \mathrm{~mm})$ and implanted onto culture media.

Culture media composed of mineral salts and vitamins of Murashige and Skoog (1962) with 2\% sucrose and $800 \mathrm{mg} / \mathrm{L}$ Polyvinylpyrrolidone (PVP). Only agar solidified media $(0.7 \%)$ were used.

All chemicals used were of analytical grade (British Drug House, E. Merck, Sigma and Difco). The following combinations of growth supplements were used for callus initiation.

1. MS Basal medium + 2,4-D $(5 \mathrm{mg} / \mathrm{L})+\mathrm{Kn}(0.5 \mathrm{mg} / \mathrm{L})$

2. MS Basal medium + 2,4-D (2 mg/L)

3. MS Basal medium + NAA $(1 \mathrm{mg} / \mathrm{L})+\mathrm{IAA}(0.2 \mathrm{mg} / \mathrm{L})$ $+\mathrm{BA}(1 \mathrm{mg} / \mathrm{L})$.

Callus was successfully maintained for 8 months with a passage period of 3 weeks on MS(2) medium.

Culture media in tubes were autoclaved at 15 $\mathrm{lbs} / \mathrm{cm}^{2}$ for 15 minutes. Cultures were incubated at $25 \pm 2^{\circ} \mathrm{C}$, exposed to an artificial neon light of $200 \mathrm{\mu m} / \mathrm{m}^{2} /$ sec with dark light cycles of $8 / 16$ hours.

Phytochemical Examination

Fresh callus $(100 \mathrm{gm})$ at the end of six week period was separated from the media and washed with double distilled water and lyophilised. The lyophilised callus powder was extracted exhaustively with $n$-hexane in soxhlet apparatus. The hexane fraction was separated and the marc was dried and extracted with ethyl acetate followed by another extraction with methanol.

The hexane fraction was dried and to the residue chloroform was added. The chloroform soluble fraction was separated to which hexane was added and kept at room temperature. A white residue (A) was obtained positive to sterols. The chloroform insoluble hexane fraction was a greasy yellow semisolid $(60 \mathrm{mg})$. The white residue (A), $(25 \mathrm{mg})$ was chromatographed on a silicagel column $(1.5 \times 20 \mathrm{~cm})$. The column when eluted with hex: $\mathrm{CHCl}_{3}$ 
(50:50), $\mathrm{CHCl}_{3}$ (100), $\mathrm{CHCL}_{3}: \operatorname{EtOAC}(70: 30)$ gave spots corresponding to 2 phytosterols. A silicagel TLC of the fraction with hex: $\mathrm{CHCl}_{3}:$ EtOAC $(70: 20: 10)$ indicated homogeneity of the samples.

Ethyl acetate fraction when partitioned with ether and chromatographed on silicagel column $(1.5 \times 20 \mathrm{~cm})$ gave fractions positive to phenolics. The etheretoAc (50:50) fraction upon repeated crystallization in acetoneether mixture gave pale yellow crystals $(8 \mathrm{mg})$ which was identified as a flavanoidal glycoside by chemical degradation and spectral analysis.

Methanol fraction when chromatographed on silicagel column gave fractions positive to phenols. A TLC of the fractions with authentic phenols was carried out using the following systems. $\mathrm{CHCl}_{3}$ :methanol (80:20), EtOAC:methanol:HAC (80:18:2) and $2 \% \mathrm{HCOOH}$.

Phytosterols were characterised by chromatography and spectroscopy. Silicagel TLC of the samples with authentic samples of cholesterol, cholesterol acetate, stigmasterol, $\beta$-sitosterol was carried out. Cochromatography of a mixture of authentic sterols and sample was carried out in solvent systems hex: $\mathrm{CHCl}_{3}:$ EtOAC (70:20:10), $\mathrm{CHCl}_{3}$ :hex (50:50), ButOH:HAC: $\mathrm{H}_{2} \mathrm{O}(50: 40: 10)$. The IR spectra were recorded on Perkin-Elmer IR spectrophotometer by the nujol method.

The flavanoidal glycoside $(5 \mathrm{mg})$ was dissolved in $20 \% \mathrm{HCL}(6 \mathrm{ml})$ and boiled for 10 minutes to hydrolyse it. The solution was cooled after addition of water $(100 \mathrm{ml})$, then it was washed thrice with benzene and dried in vacuum. The yield of aglycon was $3.2 \mathrm{mg}$. The aglycon when treated with Shinoda's reagent gave a bright red colour which was identical with that of authentic kaempferol. Chromatographic analysis was done on Whatman No.10 paper. Solvent systems used were isoprop: $\mathrm{NH}_{3}: \mathrm{H}_{2} \mathrm{O}(80: 10: 10), 2 \% \mathrm{HCOOH}$, benzene:HAC: $\mathrm{H}_{2} \mathrm{O}(40: 40: 20)$.
Analysis of phenols in methanol fractions: Chromatographic analysis was done with paper on Whatman No.10 paper and TLC on silicagel. Authentic samples tried include, 2,3-dihydroxybenzaldehyde, 3,4-dihydroxyphenylacetic acid, DL-4-hydroxy 3-methoxy mandelic acid, 3,5-dihydroxyphenylacetic acid, protocatechuic acid, t-cinnamic acid, p-coumaric acid. Spots were identified by fluorescence and $R_{f}$ values. Freshly diazotised $P^{-}$ nitroaniline and sodium hydroxide solutions were used as spray reagents.

\section{RESULTS AND DISCUSSION}

Callus from the shoot segments of E.tereticornis were induced under light at $25 \pm 2^{\circ} \mathrm{C}$. The callus was obtained with all the three MS (1),(2) and (3) media tried. Callus was white and friable in medium supplemented with 2,4-D with or without $\mathrm{Kn}$ whereas the medium containing BA, NAA and IAA produced coloured compact slightly nodulated callus. The callus grew vigorously in MS(2) media and required subculturing every three weeks. During routine passage, portions of the callus were seen to develop red pigment. The chemical constituents of the callus were repeatedly extracted in $n$ hexane, EtOAc and methanol. The hexane fraction upon partition with $\mathrm{CHCl}_{3}$ and the subsequent silicagel column chromatography of $\mathrm{CHCl}_{3}$ soluble fraction afforded pure fractions of a major and two minor sterols identified by chromatographic behaviour on TLC. IRspectra of major sterol $-3200 \mathrm{~cm}^{-1}(-\mathrm{OH}), \quad 1800 \mathrm{~cm}^{-1}(\mathrm{C}=\mathrm{C}), \quad 800 \mathrm{~cm}^{-1}$ $\left(-\mathrm{CH}_{2-}\right)$ was superimposable with authentic $\mathrm{B}$-sitosterol $3200 \mathrm{~cm}^{-1}, 1750 \mathrm{~cm}^{-1}, 900 \mathrm{~cm}^{-1}$. Quantitatively the components of phytosterols in the callus were different with $\beta$-sitosterol as the main component (70\%), stigrridsterol and cholesterol present only in trace amounts.

The ultra violet absorption spectra of the aglycon measured in methanol containing $0.01 \% \mathrm{HCl}$ had an absorption maxima of carbonyl group at $315 \mathrm{~nm}$ (kaempferol

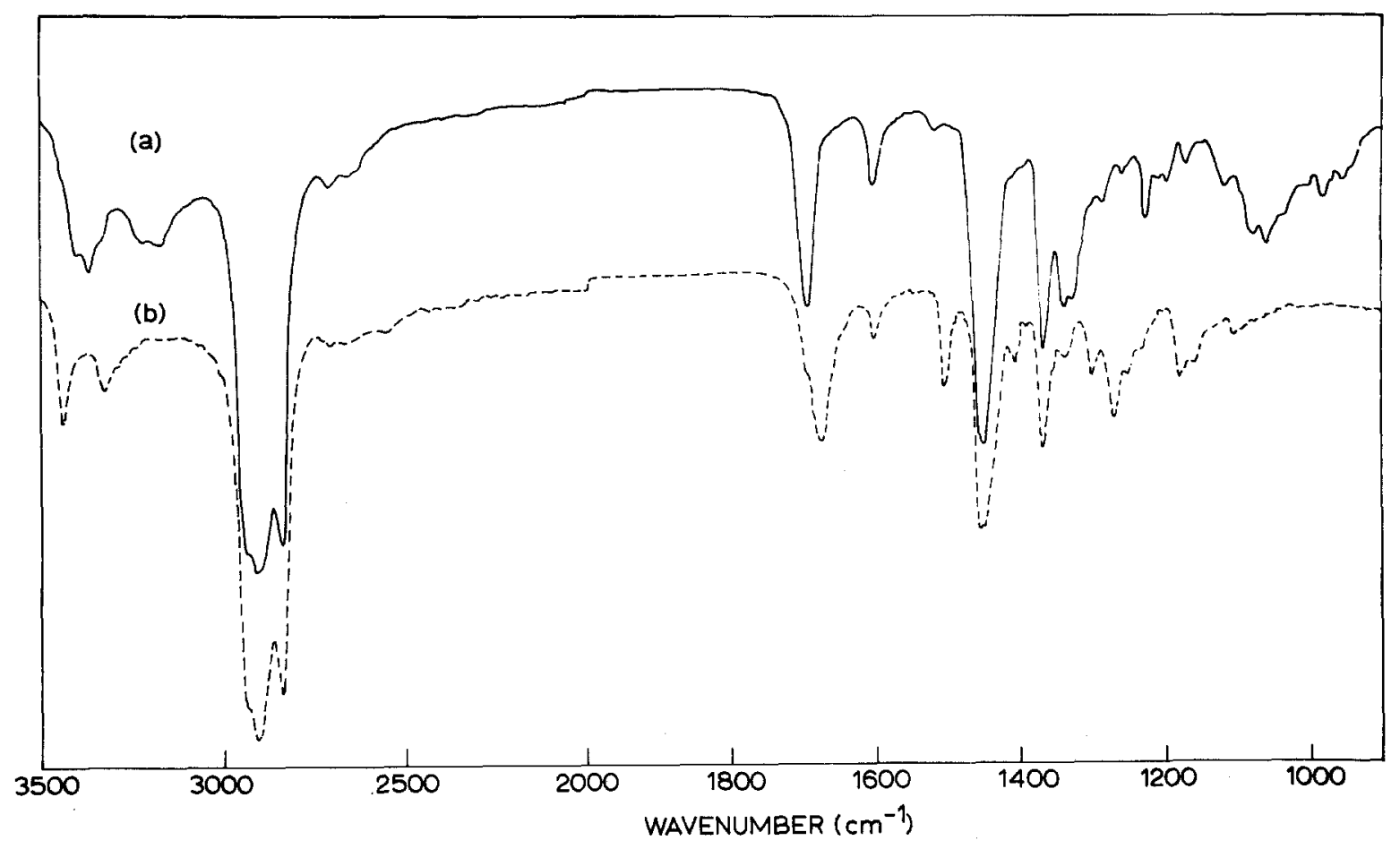

Fig.1. IR spectra of the flavanoidal aglycon from cultured cells of E.tereticornis

Continuous line: Kaempferol, broken line: sample. 
$320 \mathrm{~nm}$ ) and aromatic peak at $280 \mathrm{~nm}$ (kaempferol $280 \mathrm{~nm}$ ). The IR spectra of the sample - $3420 \mathrm{~cm}^{-1}, 3380 \mathrm{~cm}^{-1}$, $3220 \mathrm{~cm}^{-1}, 3180 \mathrm{~cm}^{-1}$ (multiple OH peaks), strong peak at $1700 \mathrm{~cm}^{-1}$ (carbony1), $1600 \mathrm{~cm}^{-1}$ (Aromatic) and kaempferol - $3430 \mathrm{~cm}^{-1}, 3350 \mathrm{~cm}^{-1}, 3300 \mathrm{~cm}^{-1}, 3150 \mathrm{~cm}^{-1}, 1700 \mathrm{~cm}^{-1}$, $1600 \mathrm{~cm}^{-1}$ was superimposable. We identified the aglycon moiety by hydrolysing the glycoside.Qualitative analysis, chromatographic and spectral data proved that aglycon was kaempferol. The Fehlings reaction was positive indicating the glycosidic linkage (Fig.1, Table 1).

The phenolics of the methanol fraction upon silicagel chromatography afforded fractions positive to phenolics identified by spot tests with freshly diazotised p-nitroaniline and $\mathrm{NaOH}$ solutions. We could identify only two phenolics $\mathrm{P}_{1}$ and $\mathrm{P}_{2}$ by chromatography with authentic samples. The IR spectra of $\mathrm{P}-3350 \mathrm{~cm}^{-1}$ $(-\mathrm{OH}), 1650 \mathrm{~cm}^{-1}$ (carbonyl), $1660 \mathrm{~cm}^{-1}$ (Aromatic) and 2,3-dihydroxybenzaldehyde $-3300 \mathrm{~cm}^{-1}, 1650 \mathrm{~cm}^{-1}$, $1600 \mathrm{~cm}^{-1}$ and $\mathrm{P}_{2}$ - split peak at $3400 \mathrm{~cm}^{-1}, 3350 \mathrm{~cm}^{-1}$ (-OH groups), $1700 \mathrm{~cm}^{-1}$ (carbonyl), $1590 \mathrm{~cm}^{-1}$ (aromatic) and 3,4-dihydroxyphenylacetic acid - $3440 \mathrm{~cm}^{-1}, 3320$ $\mathrm{cm}^{-1}, 1700 \mathrm{~cm}^{-1}, 1600 \mathrm{~cm}^{-1}, 900 \mathrm{~cm}^{-1}$ were superimposable.

Table 1

Properties of the aglycon from the cultured cells of E. tereticornis

\begin{tabular}{|c|c|c|c|c|c|}
\hline & \multicolumn{3}{|c|}{$R_{f}$ values $(X 100)$} & \multicolumn{2}{|c|}{ Spectral Data } \\
\hline & $\begin{array}{l}\text { Isoprop: } \\
\mathrm{NH}_{3}: \mathrm{H}_{2} \mathrm{O} \\
80: 10: 10\end{array}$ & $\begin{array}{l}\text { Benzenc: } \\
\mathrm{HAC}: \mathrm{H}_{2} \mathrm{O}\end{array}$ & $\stackrel{2 \%}{\mathrm{HCOOH}}$ & $\lambda \max$ & $(n m)$ \\
\hline $\begin{array}{l}\text { Sample from } \\
\text { cultured } \\
\text { cells }\end{array}$ & n & 30 & 70 & 315 & 280 \\
\hline $\begin{array}{l}\text { Authentic } \\
\text { kaempferol }\end{array}$ & 45 & 28 & 65 & 320 & 280 \\
\hline
\end{tabular}

During the tissue culture of E.tereticornis the accumulation of phenolics in the absence of PVP in the culture media was a routine problem which lead us to investigate the chemical composition of the aromatic metabolites, in cultured cells. To our knowledge, this is the first report on the phytochemistry of the callus of Eucalyptus although report of flavanoidal glycosides from the leaves of E.citriodora, E. ovata, E.camaldulensis are available (Dayal Rameshwar 1980, 1981, Wollenweber 1981, Abd-Alla 1980). Abd-Alla (1980) identified kaempferol-3-glycoside from the leaf of E. camaldulensis. We report for the first time isolation of kaempferol glycoside from cultured cells of E.tereticornis. It appears, that a major hydroxylation system is active as seen from the nature of aromatic products in the callus of E.tereticornis. We believe it is possible to alter the biosynthetic profile of phenolics in the callus by changing cultural conditions like light and hormonal manipulation.

\section{ACKNOWLEDGEMENT}

We wish to acknowledge Dr. Dayal Rameshwar, Forest Research Institute, Dehradun for authentic samples and Prof.Y.Yamada for the encouragement to first author during his recent visit to Kyoto, Japan.

\section{REFERENCES}

Abd-Alla Mohamad, F El-Negoumy, Sabry, t El-Lakany, M Hosny Saleh, Nabrel AM (1980) Phytochemistry 19: (12) 2629

Bennet JR, McComb JA (1982) Aust For Res 12: 121

Cannon JR, Metcalf $\mathrm{BW}$, Raston $\mathrm{Cl}$, White $\mathrm{AH}$ (1981) Aust J Chem 34: (5) 1135

Dayal Rameshwar (1980) Curr Sci 49: (3) 116

Dayal Rameshwar (1982) J Ind Chem Soc 59: (8) 1008

De Fossard RA (1978) In: Symp Plant Tissue Culture, Sci Press, Beijing: pp 425

Durand-Cresswel R, Bonlay M, Franclet A (1982) In: Bonga JM, Durzan DJ (eds) Tissue Culture in Forestry: Martinus Nijhoff/Dr.W Junk Publishers, pp 150

Gupta PK, Nadgauda RS, Hendre RR, Mascarenhas $A F$, Jagannathan $V$ (1978) In: Abst of the Ali India Symposium 3rd Conference Plant Tissue Culture, Dept of Botany, MS University Baroda, pp 63

Gupta PK, Mascarenhas AF, Jagannathan V (1982) Plant Sci Letts 20: 195

Gupta PK, Mehta VJ, Mascarenhas AF (1983) Plant Cell Reports 2:, 296

Hartney VJ, Barker PK (1980) In: Symp. and Workshop on Genetic Improvement and Production of Fast Growing Tree Species, Publ IUFRO, Brazil, pp 1

Linchan Huayne Yu Gongye, Chinese Academy of Forests, Research Inst of Chemical Processing and Utilization of Forest Resources (1981) 1: (1) 39 Chem Abs No 17278 , Vol 96

Mehra-palta A (1982) Plant Sci Letts 26: 1

Qin GW, Chem ZX, Wang HC, Qian MK (1981) Hua Hsuch Hsuch Psa 39: (1) 83 Chem Abs 61678, Vol 95, 1981

Sankara Rao K, Venkateswara R (1985) Plant Sci 40: 51

Sawada T, Kazuka M, Komiya T, Amno T, Goto M (1980) Chem Pharm Bull 28: (8) 2546

Wollenweber Eckhard, Kohrst Gielsa (1981) z Naturforsch c Biosci 36C: (11-12) 913 